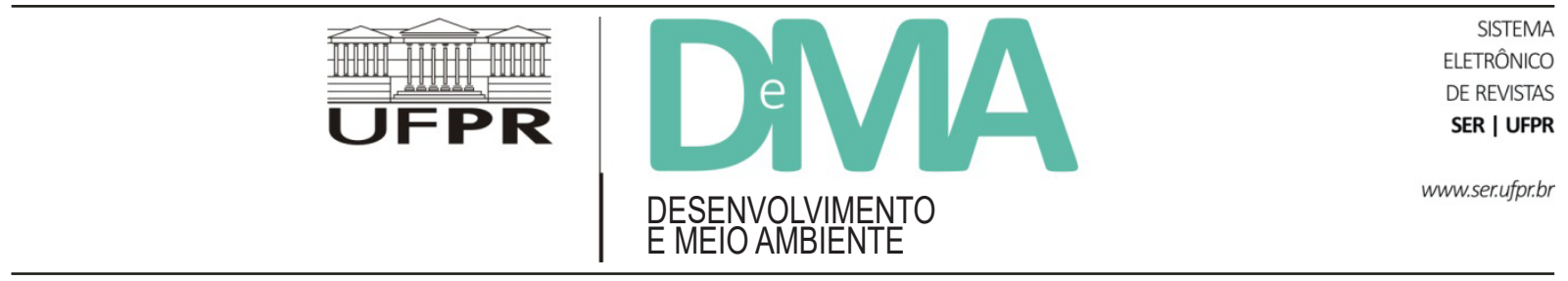

\title{
Inventário de Práticas Agroecológicas na Metodologia "de Camponês/a a Camponês/a" no Ceará: um instrumento para descolonizar o território e (re)valorizar o conhecimento camponês
}

\section{Inventory of Agroecological Practices as part of the "Peasant to Peasant" Methodology in Ceará: an instrument to decolonize a territory and (re)value peasant knowledge}

Ivanete Ferreira FERNANDES ${ }^{1}$, Lia Pinheiro BARBOSA ${ }^{2 *}$, Cosma dos Santos DAMASCENO ${ }^{3}$, Peter Michael ROSSET $^{4,5,6,7}$

\footnotetext{
${ }^{1}$ Escola de Ensino Médio do Campo Florestan Fernandes, Monsenhor Tabosa, CE, Brasil.

${ }^{2}$ Professora Permanente do Programa de Pós-Graduação em Sociologia (PPGS) e do Mestrado Acadêmico Intercampi em Educação e Ensino (MAIE), Universidade Estadual do Ceará (UECE), Fortaleza, CE, Brasil.

${ }^{3}$ Escola de Ensino Médio do Campo Francisco Araújo Barros, Itarema, CE, Brasil.

${ }^{4}$ Professor-investigador do El Colegio de la Frontera Sur (ECOSUR), San Cristóbal de Las Casas, Chiapas, México.

${ }^{5}$ Profesor BPV-FUNCAP del Programa de Pós-Graduação em Sociologia (PPGS), Universidade Estadual do Ceará (UECE), Fortaleza, CE, Brasil. ${ }^{6}$ Professor Colaborador do Programa de Pós-Graduação em Desenvolvimento Territorial na América Latina e Caribe (TerritoriAL), Universidade Paulista (UNESP), São Paulo, SP, Brasil.

${ }^{7}$ Professor visitante, Social Research Institute (CUSRI), Chulalongkorn University (Chula), Bangkok, Tailândia.

*E-mail de contato: lia.barbosa@uece.br
}

Artigo recebido em 8 de novembro de 2020, versão final aceita em 7 de abril de 2021, publicado em 30 de novembro de 2021.

RESUMO: Neste artigo abordamos o uso do inventário ou mapeamento de práticas agroecológicas, que faz parte da metodologia "de Camponês/a a Camponês/a" $(\mathrm{CaC})$ para promover a territorialização da agroecologia camponesa, como método também para a descolonização epistêmica de um território. A chamada Revolução Verde envolveu a imposição de tecnologias e conhecimentos exógenos, provocando a fragmentação e desvalorização dos conhecimentos e práticas agrícolas camponesas locais, adaptados às condições locais. Na verdade, foi uma colonização epistêmica. A metodologia $\mathrm{CaC}$ é baseada no protagonismo camponês para recuperar e socializar 
o conhecimento agroecológico. Utilizamos o caso do processo CaC no Assentamento Santana, assentamento de reforma agrária do Movimento dos Trabalhadores Rurais Sem Terra (MST) no Ceará, Brasil, com o intuito de demonstrar e analisar o inventário de práticas como uma ferramenta coletiva de descolonização na territorialização da agroecologia.

Palavras-chave: inventário de práticas; agroecologia; camponês a camponês; territorialização; descolonização.

ABSTRACT: In this article we address the use of an inventory or mapping of agroecological practices, which is part of the

"Peasant to Peasant" methodology (PtP) for promoting the territorialization of peasant agroecology, as a method that also serves for the epistemic decolonization of a territory. The so-called Green Revolution involved the imposition of exogenous technologies and knowledge, causing the fragmentation and devaluing of local peasant knowledge and farming practices adapted to local conditions. In effect, it was an epistemic colonization. The $\mathrm{PtP}$ methodology is based on peasant protagonism to recover and socialize agroecological knowledge. We use the case of the PtP process in the Santana land reform settlement of the Landless Rural Workers Movement (MST) in Ceará, Brazil, to demonstrate and analyze the inventory of Practices as a collective tool for decolonization as part of the territorialization of agroecology.

Keywords: inventory of practices; agroecology; peasant to peasant; territorialization; decolonization.

\section{A modo de introdução}

A realidade da agricultura camponesa no mundo, e em particular no semiárido cearense, é tal que o modelo tecnológico convencional promovido tanto pelos governos quanto pelo agronegócio é cada vez mais inviável para os pequenos produtores (Sampaio \& Lima, 2007; Costa, 2017; Rosset \& Altieri, 2017; Fontes, 2019). Em um contexto em que o paradigma de desenvolvimento do capitalismo se consolida e aprofunda os processos de expropriação territorial e de impactos socioambientais, a agroecologia se torna uma saída promissora, não só em termos de uma mudança nos padrões de produção agropecuária, mas fundamentalmente por se contrapor, radicalmente, à forma como, historicamente, o capitalismo concebe o território, compreendo-o como fonte inesgotável de acumulação.
Nessa perspectiva, para realizar uma transformação ou transição agroecológica bemsucedida, é necessário ter conhecimento sobre a concepção da agroecologia e a organização de um processo social. Ao contrário do padrão agrário capitalista caracterizado, grosso modo, por relações de produção baseadas na proletarização camponesa, no uso intensivo de maquinaria e de agrotóxicos, latifúndios de monocultivo e processos de desterritorialização e descampenização, todos aplicados de forma semelhante em realidades muito diferentes (Grammont, 2006; Moyo \& Yeros, 2008; Stedile, 2013), a agroecologia, além de ser uma ciência e um movimento, é um conjunto de princípios para uma transformação desse modelo, não só em termos produtivos, mas das relações sociais, e que são materializados de forma diferente em cada contexto local (Rosset, 2015; Rosset \& Altieri, 2017; Fontes, 2019). 
Para uma abordagem crítica de como tem se dado o desenvolvimento do capitalismo, há de se ter presente que sua consolidação não se deu apenas por um fator da estrutura econômica, em termos da mudança da base material das relações produtivas. Houve, do ponto de vista subjetivo, a imposição de um paradigma de conhecimento que sustenta, secularmente, a racionalidade capitalista e as relações sociais intrínsecas à sua expansão (Barbosa, 2019). O reconhecimento desse plano subjetivo é fundamental para pensarmos os possíveis caminhos de enfrentamento do capitalismo a partir dos processos sociais e políticos alavancados pelo campesinato, em seus modos de ser, viver e produzir (Silva, 2014). Isto significa que o conhecimento camponês local é de suma importância, especialmente porque, na maioria dos biomas e ambientes ao redor do mundo, os camponeses produziram alimentos sem agrotóxicos durante séculos ou milênios, a partir de uma matriz de conhecimento ancestral em torno ao convívio territorial, milenarmente apreendida, e que nos revela a existência de um conhecimento camponês e de práticas camponesas que permitem a produção adequada a cada realidade. Entretanto, muitos dos membros de uma população camponesa local perderam, ao longo do tempo, esses conhecimentos e práticas que lhes permitiam uma coexistência em equilíbrio com a natureza, de modo que hoje esses conhecimentos e práticas estão dispersos entre apenas algumas poucas famílias camponesas.

A perda do conhecimento local é tipicamente o resultado de décadas de imposição de conhecimentos exógenos por meio de projetos, condições de crédito, assistência técnica e a publicidade onipresente em favor do modelo de monocultura dependente de agrotóxicos que caracteriza a chamada Revolução
Verde (Shiva, 2003; Rosset \& Altieri, 2017). Este conhecimento supostamente "moderno" tem sido ensinado há anos, em detrimento da transmissão do conhecimento camponês. Nesse sentido, alguns membros da população camponesa não aprenderam o conhecimento tradicional das práticas camponesas (que são principalmente de natureza agroecológica), enquanto outros sabem algo sobre elas, mas desvalorizam seus próprios conhecimentos e práticas tradicionais, por considerá-los como "atrasados" ou "primitivos", um motivo de vergonha. Em outras palavras, nesse processo histórico de imposição de uma racionalidade capitalista, tem havido uma "colonização do conhecimento", por meio da imposição do chamado "conhecimento técnico" que se origina nos países do Norte e que, geralmente, não necessariamente é adequado à realidade da agricultura camponesa.

Ainda assim, em quase todas as comunidades camponesas do mundo, apesar dessa colonização, ainda existem pessoas e famílias, embora muito dispersas, que mantêm conhecimento de práticas que abordam a superação de muitos dos obstáculos à produção no ambiente local. Tipicamente algumas famílias podem conhecer e usar algumas práticas, enquanto outras famílias podem conhecer e usar outras, mas ninguém sabe ou usa todas elas, além daquelas pessoas que podem não as conhecer ou usar nenhuma. No entanto, o fato de que essas práticas sejam locais, já comprovadas ao longo do tempo que realmente funcionam sob condições locais, podem ser um indicativo de que sejam melhores do que as práticas importadas de outros lugares, mesmo quando estas também sejam "agroecológicas".

Sendo assim, um primeiro passo para criar um processo social, por exemplo, de "camponês a camponês", para promover uma transição 
coletiva para a produção agroecológica, é resgatar esses conhecimentos e essas práticas. Em outras palavras, "descolonizar o conhecimento local". $\mathrm{Na}$ prática, isto significa realizar um processo de identificação das famílias que ainda possuem e utilizam cada conhecimento e cada prática, de forma sistemática, como um primeiro passo para uma eventual sistematização e socialização desses conhecimentos e práticas em toda a comunidade. Ou seja, realizar um "inventário" ou "mapeamento" de conhecimentos e práticas existentes no território (MST-CE, 2019).

No presente artigo apresentaremos uma reflexão em torno de um elemento fundamental do processo de transição e territorialização agroecológica, qual seja, o Inventário de Práticas Agroecológicas, com o intuito de destacar seu papel educativo e pedagógico para a descolonização do conhecimento em território camponês, estratégia imprescindível à consolidação da agroecologia enquanto princípio e projeto político do campesinato. Para tanto, relatamos um estudo de caso no estado do Ceará, nordeste brasileiro, no Assentamento Santana, assentamento de reforma agrária localizado em uma região com um determinado conjunto de condições ambientais, sociais e econômicas característicos do semiárido cearense. Concebemos, elaboramos e aplicamos um inventário, baseado na metodologia "de Camponês/a Camponês/a" ( $\mathrm{CaC})$, com resultados notáveis, os quais apresentamos aqui.

Em síntese: antes de iniciarmos o processo, as pessoas diziam que "não praticavam agroecologia" e não "conheciam práticas agroecológicas". Entretanto, nosso inventário revelou que, entre as famílias da comunidade, mais de 40 práticas agroecológicas estavam sendo usadas, além do fato de estarem dispersas e isoladas no assentamento e seu entorno. Isso demonstra que a comunidade possui um rico acervo de conhecimentos e práticas que podem resolver muitos dos principais problemas de produção, e essa é a matéria-prima necessária para iniciar um processo de socialização do conhecimento pela metodologia $\mathrm{CaC}$ para o escalonamento e a territorialização da agroecologia. De fato, estes resultados, quando apresentados na assembleia da comunidade, já geraram entusiasmo por um processo de agroecologia nesse território camponês.

\section{A centralidade da agroecologia para o projeto político do campesinato}

As organizações camponesas do mundo têm priorizado, cada vez mais, a agroecologia como elemento estratégico, tanto para fortalecer a resistência ao avanço do capital nos territórios, como para construir um projeto societário para a humanidade e a Mãe Natureza. Alguns dos raciocínios por trás deste consenso a favor da agroecologia são (Via Campesina, 2013a; Batista, 2014; Rosset \& Martínez-Torres, 2016; Barbosa \& Rosset, 2017a; Rosset \& Barbosa, 2019; Rosset \& Barbosa, 2021):

- Respeito e cuidado com a Mãe Terra e os comuns;

- Produzir alimentos saudáveis sem agrotóxicos, cuidar da nossa saúde e a saúde de nossas famílias, das crianças e da população em geral;

- Construir um modelo de produção que seja coerente com nossa luta e nosso discurso em defesa do território e da reforma agrária integral e popular; 
- É componente essencial da construção da soberania alimentar;

- Permite ser mais resilientes ante as mudanças climáticas, produzir com menos água, e ajudar a esfriar o planeta;

- É enfrentar diretamente ao capital no campo (parando de comprar seus insumos e de usar seu modelo de produção), bem como transformar o modelo produtivo;

- Responde a uma forte demanda de participação e reconhecimento, a partir das mulheres e da juventude;

- Promove uma mudança das relações sociais, tornando-as mais humanizadas e horizontais;

- Reduz a dependência do crédito e dos insumos comprados, dos custos de produção e, portanto, do endividamento, ao passo que melhora o lucro líquido da produção;

- Construir a autonomia camponesa em seus territórios;

- É não competir no jogo do agronegócio no campo e com suas regras; ao contrário, é virar o jogo, tornando-o mais favorável a nós, os camponeses;

- É a (re)construção de uma cultura de campo, uma cultura de resistência, de luta e de autonomia;

- Reduz a jornada de trabalho agrícola, ao reforçar o uso da inteligência e da criatividade, e criar um ambiente mais agradável de trabalho na agricultura;

- Oferece mais oportunidades para a juventude permanecer no campo;

- Enquanto a monocultura convencional reforça a autoridade do homem na produção familiar, a diversificação agroecológica pode descentralizar as funções e áreas de tomada de decisões produtivas, e até a renda de todos os membros da família, o que reduz o peso do patriarcado dentro da família camponesa.

Mas não é suficiente escolher a agroecologia, não basta decidir que por meio dela se promova uma melhor matriz produtiva para a agricultura camponesa, ou mesmo saber fazer agroecologia no plano técnico (Rosset, 2017). O modelo convencional da agricultura industrial baseado em monoculturas e insumos agroquímicos tem raízes profundas, mesmo entre o campesinato. Décadas de propaganda comercial, assistência técnica convencional, requisitos de programas de crédito, bem como o sistema educacional em todos seus níveis, fizeram com que o modelo convencional parecesse normal e, até mesmo, desejável. As mesmas forças têm gerado quase um consenso de que a alternativa agroecológica é uma fantasia, uma ilusão, impossível na prática. Tudo isso tem raízes profundas para que seja superado com o mero discurso em favor da agroecologia. Também não é suficiente, embora seja necessário, ter práticas agrícolas técnicas e ecológicas que funcionam bem em termos produtivos e econômicos (Rosset, 2015; 2017; Rosset et al., 2011; Khadse et al., 2017).

$\mathrm{Na}$ verdade, em quase todas as regiões do mundo, já existem, de forma abundante, boas alternativas agroecológicas no domínio técnico como, por exemplo, maneiras de fazer compostagem e biopreparações, opções de culturas consorciadas, sementes adaptadas à seca, adubos verdes, curvas de nível, integração de plantas e animais, sistemas agroflorestais, entre outras. O problema é que poucas pessoas realmente usam essas alternativas, ainda que elas tenham sido cientificamente comprovadas como sendo superiores. Na maioria dos 
casos, o real gargalo não é a disponibilidade de alternativas, mas sim a falta de um processo social para impulsionar sua adoção. E, como veremos, o que mais convence a um camponês ou camponesa de que uma alternativa, sim, funciona, é visitar a outro camponês ou camponesa igual a eles, que a usa de forma bem-sucedida. Isto deve ser levado em consideração em qualquer processo social de promoção agroecológica (Machín Sosa et al., 2012; Rosset et. al., 2011; 2015).

Por outro lado, a abordagem da agroecologia na perspectiva camponesa não se limita a uma mera adoção de práticas agroecológicas, por vezes compreendidas como produção de alimentos orgânicos, ou seja, sem o uso de agrotóxicos. A agroecologia se vincula a um processo históricopolítico de defesa da terra e da realização da reforma agrária integral e popular, além de almejar uma ruptura radical com os padrões de dominação e exploração enraizados no capitalismo, nas relações sociais de produção. Em outros termos, a concepção de agroecologia para o campesinato requer a transformação das relações produtivas, a superação do patriarcado, do colonialismo, do racismo, o equilíbrio da convivência com a natureza e os seres vivos e não vivos. Portanto, a agroecologia se inscreve em um contexto histórico de luta política contra as estruturas de dominação erigidas pelo capitalismo, de disputa hegemônica do campesinato, com visas a uma emancipação humana.

$\mathrm{Na}$ história contemporânea, são muitos os movimentos camponeses que constroem processos políticos e sociais alinhados a essa concepção da agroecologia como estratégia da luta do campesinato. Entre eles, destaca-se a Via Campesina Internacional (LVC), que articula organizações camponesas, de trabalhadores rurais, de povos tradicionais, pescadores, pastores, movimentos indígenas, entre outros, nos cinco continentes do mundo (LVC, 2013; Batista, 2014; Val et al., 2019). No Brasil, o Movimento dos Trabalhadores Rurais Sem Terra (MST) é uma das organizações fundadoras da LVC, e nos fundamentos do seu Programa Agrário apresenta um conjunto de objetivos da Reforma Agrária Popular para a consolidação de "mudanças estruturais na forma de usar os bens da natureza, que pertencem a toda sociedade, na organização da produção e nas relações sociais no campo" (MST, 2014, p. 35).

Nesse sentido, a agroecologia constitui um dos pilares do Programa de Reforma Agrária Popular do MST, articulada à crítica ao padrão de desenvolvimento impulsionado pelo capitalismo no campo, sobretudo no agronegócio, ao tempo que se vincula à luta pela democratização do acesso à terra para o campesinato, a organização da produção agrícola pela matriz tecnológica de base agroecológica para a transformação dos modos de produção e distribuição da riqueza na agricultura, e na gênese de uma mudança intelectual e moral, a partir da Educação do Campo, que fortaleça a identidade camponesa e seu vínculo com o território como espaço de reprodução social da vida (MST, 2014).

Associada a uma dimensão política de defesa do território e de enfrentamento do agronegócio, "a agroecologia inclui: o cuidado e defesa da vida, produção de alimentos, consciência política e organizacional" (LVC, 2009). Ademais, a agroecologia é "inseparável da luta pela soberania alimentar, pela defesa e recuperação de territórios, pela reforma agrária e urbana, e pela cooperação e aliança entre os povos do campo e da cidade" 
(Guhur \& Toná, 2012, p. 64). Com base no exposto, demarcamos que nossa reflexão acerca do Inventário das Práticas Agroecológicas emerge desse terreno político e teórico, isto é, de uma abordagem da agroecologia a partir de um processo socio-político impulsionado pelos movimentos camponeses e das estratégias por eles articuladas na confrontação do capitalismo no campo.

Para disputar e interpelar o projeto territorial do capital no campo, temos que levar a agroecologia camponesa e popular à escala territorial, como parte de nossa concepção de Reforma Agraria Popular. Levar a agroecologia à grande escala, alcançar sua massificação ou territorialização significa que, ao invés de ser praticada por poucas famílias em um território pequeno, deve ser praticada por muitas famílias em um território amplo. Em outros termos, o enfrentamento do capitalismo no campo exige disputar hegemonicamente os territórios, no sentido de sustentar uma concepção territorial em perspectiva agroecológica camponesa, objetivo a ser alcançado pelo campesinato (Mier y Terán, 2018; Barbosa \& Rosset, 2017a; Rosset \& Barbosa, 2019; Val et al., 2019).

As aprendizagens da LVC nos 5 continentes, e muitas outras experiências, ensinam-nos a necessidade de construção deliberada e sistemática dos processos sociais de transformação agroecológica. Mas estes processos são complexos, pois há muitos fatores implicados na realização da ampla adoção da agroecologia pelo campesinato. No entanto, a complexidade pode ser levada em conta no desenho de um processo com intencionalidade educativa e política. A seguir, apresentamos a lista de fatores que foram identificados como determinantes para o êxito de vários processos de agroecologia, e que nos apresenta possibilidades a serem consideradas no planejamento de um processo de territorialização da agroecologia (Rosset et al., 2011; Rosset, 2015; McCune et al., 2016; Khadse et al., 2017; McCune et al., 2017; Rosset \& Altieri, 2017; Mier y Terán et al, 2018; Giraldo \& McCune, 2019).

- A organização e o tecido social (a organicidade) são fundamentais para o impulso do processo social da territorialização agroecológica. Ainda que uma família camponesa isolada transforme seu processo produtivo em um processo agroecológico exemplar, talvez ninguém possa aprender com eles ou imitá-los. Mas se fazem parte de um processo organizado de visitas de intercâmbio e aprendizagem horizontal, elas podem ser parte de um efeito multiplicador significativo. É necessário a construção intencionada de processos territoriais, baseados na organicidade e na ação coletiva;

- O protagonismo camponês desencadeia processos de valorização e resgate de saberes, de convencimento, de inovação e de socialização de práticas e conhecimento. Para um camponês ou camponesa é mais provável acreditar em outro(a) camponês ou camponesa que está usando, com êxito, as práticas agroecológicas, do que acreditar no discurso puro de um técnico ou dirigente. $\mathrm{O}$ intercâmbio e o diálogo de saberes são fundamentais para a transmissão horizontal da agroecologia entre camponeses e camponesas.

- A iniciativa das mulheres, a criatividade e a energia da juventude podem ser fatores-chave no êxito da agroecologia. Há muitos processos de agroecologia impulsionados por mulheres, e até mesmo nos casos em que apenas os homens 
são reconhecidos nos espaços externos, são as mulheres, dentro da unidade familiar, que promovem a transformação agroecológica, muitas vezes motivadas pelas preocupações com a saúde devido às contaminações por agrotóxicos e por um desejo de comida saudável. E a maioria dos jovens só estaria dispostos/ as a ficar no campo se a sua criatividade é desafiada e vinculada a algo fascinante como a agroecologia. Dessa forma, a sua energia pode impulsar o processo de transformação.

- Um discurso motivador e mobilizador é necessário para animar as famílias camponesas a se aventurar na transformação agroecológica. Há uma variedade de discursos eficazes ao redor do mundo, de acordo com a cultura local, a história organizativa e a realidade social. Dependendo de cada caso, dos elementos e valores espirituais, religiosos, políticos, ideológicos, ambientais, de saúde, de confronto, e mesmo econômicos, podem ser parte de um discurso efetivo para motivar a agroecologia.

- O mercado tem desempenhado um papel importante na motivação de alguns dos casos de êxito agroecológico ao redor do mundo. Os mercados locais, as feiras camponesas, os mercados orgânicos, os mercados institucionais, os canais alternativos de distribuição etc., que atribuem valor aos alimentos camponeses produzidos ecologicamente, podem proporcionar um importante incentivo à mudança para uma matriz produtiva agroecológica.

- As políticas públicas podem acelerar, significativamente, os processos de transformação e escalamento, mesmo que seja, ao mesmo tempo, uma faca de dois gumes, porque podem gerar dependência e endividamento. Os programas de crédito para a produção agroecológica, bem como os programas de aquisição por instituições públicas, tais como a PNAA (Política Nacional de Abastecimento Alimentar) e o PNAE (Programa Nacional de Alimentação Escolar) no Brasil, podem assentar as bases para as cooperativas camponesas aumentarem substancialmente a sua produção agroecológica. Mas isso poderia ser um escalonamento arriscado, por exemplo, se os créditos e contratos de compra são cancelados devido a uma mudança de governo. Em uma situação assim, a produção pode entrar em colapso e as cooperativas ficarem endividadas. A alternativa é construir processos mais autônomos, baseados, por exemplo, no crescimento lento, e talvez mais sólido, dos mercados locais em alianças com organizações sociais do campo e da cidade.

- O processo de luta social na defesa da terra, da realização da reforma agrária integral e popular, coaduna com a apreensão da agroecologia como um projeto político das famílias camponesas no fortalecimento e defesa de seus territórios.

- Os processos de formação e educação agroecológicos e organizativos são fundamentais, já que fortalecem, sinergizam, e retroalimentam a todos os fatores acima. Estes postulam um papel fundamental para as Escolas do Campo e escolas de formação em potencializar os processos de territorialização da agroecologia. 


\section{Camponês a Camponês: a metodologia de maior êxito na territorialização da agroecologia}

A Metodologia "De Camponês a Camponês" $(\mathrm{CaC})$ é uma metodologia de processo social para a transição agroecológica e a territorialização da agroecologia, desenvolvida originalmente na Ásia, na década de 1920. Na América Latina foi difundida por indígenas camponeses da Guatemala, em 1972. Entre as décadas de 1970 e 1990, a Metodologia CaC se expandiu de forma exitosa nas zonas rurais de diferentes países da América Central, notadamente na Nicarágua e Honduras, adentrando também outros países, como o México e Cuba. Desde sua origem, a Metodologia $\mathrm{CaC}$ consiste em uma reação ao modelo convencional de assistência técnica, em que o/a técnico(a) é o sujeito ativo do processo e as organizações camponesas são consideradas apenas receptoras das instruções técnicas para manter um determinado padrão da produção agropecuária (Kolmans, 2006; Holt Giménez, 2008; Rosset et al., 2011; Machin Sosa et al., 2012; Val et al. 2019; Fernandes \& Barbosa, 2020).

Nessa direção, a Metodologia $\mathrm{CaC}$ nasce como uma reação ao modelo convencional de assistência técnica. Nos métodos verticais da extensão agrícola convencional, seja nos serviços públicos, nas cooperativas, e em muitos «projetos», o técnico é o sujeito ativo, o "sabichão" do processo (Holt Giménez, 2008; Rosset et al., 2011; Machín Sosa et al., 2012), isto é, aquele que detém o reconhecimento do saber considerado legítimo em relação à produção. Este método técnicocentrista não dialoga de forma satisfatória com uma filosofia política e de organização social que busca pôr a família camponesa como um sujeito central na transformação de sua realidade e de seu próprio destino. Além disso, tem limitações, no sentido de promover o enfoque agroecológico, pois este depende da aplicação de princípios - e não de receitas -, segundo a realidade local de cada estabelecimento rural camponês e de cada cooperativa. Em outros termos, uma abordagem agroecológica exige criatividade, conhecimento local, inovação e inteligência camponesa, muitas vezes não reconhecidas e valorizadas pela assistência técnica (Rosset et al., 2011; Machín Sosa et al., 2012).

No modelo de assistência técnica, a família camponesa assume um papel passivo. Quando ocorre um problema, esperam o técnico chegar de fora para resolvê-lo. Eles podem esperar por um longo período, sem tomar a iniciativa de buscar soluções. Estes métodos verticais também se autolimitam, sobretudo por alguns fatores objetivos, por exemplo, número limitado de técnicos que afeta a quantidade de famílias que cada técnico pode atender, ou ainda o orçamento, por vezes, insuficiente para garantir uma ampliação da assistência técnica. Nesse sentido, o $\mathrm{CaC}$ nasce como uma crítica à concepção tecnicista de produção agropecuária, ao tempo que se propõe como uma metodologia horizontal libertadora, dinâmica e criativa, que permita a plena participação coletiva, em que as comunidades camponesas assumam o controle de seus processos produtivos como sujeitos partícipes, em diálogo com um conjunto de saberes de vida e de luta herdados historicamente.

$\mathrm{O}$ momento pedagógico central em um processo $\mathrm{CaC}$ ocorre quando um(a) camponês(a) com um problema produtivo (por exemplo, um solo infértil ou um problema de praga no 
plantio) visita o roçado ou o quintal produtivo de outro(a) camponês(a) que já implementou com êxito uma solução agroecológica para o mesmo problema. A visita constitui a mediação pedagógica de saberes de camponeses e camponesas na resolução de problemas relacionados à produção agropecuária em perspectiva agroecológica. A aprendizagem é horizontal, de camponês a camponês e/ou de camponesa a camponesa. A base é o diálogo de saberes entre camponeses(as), e entre camponeses(as) e técnicos-facilitadores de processos (Martínez-Torres \& Rosset, 2014; Fernandes \& Barbosa, 2020).

Em 1997, a Metodologia $\mathrm{CaC}$ chegou à Cuba, a partir da colaboração da organização camponesa Unión Nacional de Agricultores y Ganaderos de Nicarágua (UNAG). Nesse país caribenho assume outra dimensão, ao tornar-se o Movimento Agroecológico de Camponês a Camponês (MACAC), graças ao estímulo e à ação política da Associação Nacional de Agricultores Pequenos (ANAP), principal organização camponesa do país. Desde então, a ANAP aperfeiçoou a metodologia e mobilizou centenas de famílias camponesas cubanas em escala nacional, impulsionando o MACAC e tornando-se uma referência na transição agroecológica e na territorialização da agroecologia não só em Cuba, mas em toda América Latina e Caribe. Importante destacar que a ANAP é uma organização membro e faz parte da Coordenação Global da Via Campesina Internacional (Rosset et al., 2011; Machín Sosa et al., 2012; Fernandes \& Barbosa, 2020).

$\mathrm{O}$ vínculo com a $\mathrm{LVC}$ responde à estratégia global do campesinato no enfrentamento do projeto territorial do capital no campo e na disputa hegemônica de uma concepção de território compreendido como espaço de reprodução da vida, em que a produção de alimentos saudáveis pela agricultura familiar camponesa, bem como a soberania alimentar são basilares na apreensão política da terra para quem nela trabalha. Nesse sentido, no âmbito das organizações da LVC e como parte constituinte da luta pela consolidação da Reforma Agrária Popular, a agroecologia emerge como princípio e projeto político, em que o impulso do escalamento, massificação ou territorialização da agroecologia em territórios camponeses é o caminho de defesa, resistência ativa e permanência no campo, de transformação das relações sociais e com a natureza, em uma perspectiva camponesa e popular (Rosset \& Barbosa, 2019; Fernandes \& Barbosa, 2020).

Um processo de metodologia $\mathrm{CaC}$ tem de ser bem estruturado, planejado, com processos de formação dos sujeitos-chave envolvidos. $\mathrm{O}$ caso mais exitoso de implementação da Metodologia CaC é o da ANAP (Rosset et al., 2011; Machín Sosa et al., 2012; Val, et al., 2019). Neste caso, é importante destacar o papel exercício pela Escola Nacional Niceto Pérez da ANAP, especialmente na promoção de processos permanentes de formação na Metodologia $\mathrm{CaC}$ junto às organizações da Via Campesina Internacional, com o intercâmbio de experiências junto às cooperativas e famílias camponesas partícipes do MACAC. Os sujeitos do MACAC são: Camponeses e Camponesas; Promotor(a); Facilitador(a); Coordenador(a) e Aliados. A Metodologia $\mathrm{CaC}$ incorpora elementos pedagógicos e ferramentas da Educação Popular, com destaque para as seguintes atividades: a) Assembleia de Associados; b) Oficinas; c) Diagnóstico Rápido Participativo (DRP); d) Visitas; e) Intercâmbios e f) Encontros (Roque Jaime, 
2019). Além disso, elabora materiais didáticos e audiovisuais, como as cartilhas da Metodologia $\mathrm{CaC}$ e o curso metodológico virtual "Escuela Campesina Multimedia: una herramienta audiovisual para difundir la agroecología", plataforma digital em que se encontra: 1. Vídeo-curso Metodologia Camponês a Camponês; 2. Vídeos sobre a agricultura camponesa agroecológica; 3 . Vídeos sobre a agricultura urbana e 4. Bibliografia sobre agroecologia e o MACAC (Fernandes \& Barbosa, 2020).

Em Cuba, os promotores(as) são mestres camponeses(as) que já utilizam técnicas agroecológicas com êxito, que recebem visitas de outros camponeses e camponesas nos seus roçados, sendo estes considerados como uma sala de aula para o ensino-aprendizagem das soluções agroecológicas aos problemas de produção. Os facilitadores(as) são pessoas que têm alguma formação técnica, que trabalham em âmbito local, e identificam os camponeses e camponesas que são potenciais promotores, os preparam e organizam o processo de visitas de intercâmbio. Os coordenadores(s) também têm formação técnica, administram e coordenam o processo de $\mathrm{CaC}$ em escala maior. Os promotores e facilitadores trabalham, também, com as escolas do campo locais. Organizam "círculos de interesse" para crianças e jovens sobre a agroecologia, e montam salas de aula auxiliares nas casas de famílias camponesas agroecológicas (promotores). Com a utilização da metodologia de $\mathrm{CaC}$ de forma muito organizada, sistemática e intencionada, com alta organicidade e uma escola camponesa para formar promotores, facilitadores e coordenadores, a ANAP conseguiu, em 15 anos, que a metade da população camponesa cubana se tornasse agroecológica, e com as maiores taxas de produtividade, algo que eles nunca teriam conseguido com seu modelo anterior de assistência técnica (Rosset et al., 2011; Machín Sosa et al., 2012; Mier y Terán et al., 2018; Val et al., 2019).

Com base no exposto, argumentamos que há uma dimensão pedagógica na Metodologia $\mathrm{CaC}$, uma vez que nesse processo de escalonamento ou territorialização da agroecologia, além da formação teórico-política, as organizações têm fomentado a elaboração e implementação de metodologias de socialização horizontal de conhecimento para o fortalecimento de processos territoriais de agroecologia (Fernandes e Barbosa, 2020). É no momento em que se visita uma experiência exitosa de aplicação de uma solução a um problema produtivo, que acontece a mediação pedagógica de um conjunto de conhecimentos camponeses na resolução de problemas relacionados à produção agropecuária em perspectiva agroecológica. Portanto, no MACAC observamos uma práxis educativo-pedagógica articulada por uma Pedagogia Camponesa Agroecológica (Barbosa; Rosset, 2017a) baseada na pedagogia do exemplo, e no diálogo de saberes entre camponeses, e entre camponeses e técnicos facilitadores de processos. Em outros termos, o exemplo e a partilha dos saberes é o segredo do êxito da Metodologia CaC, ou seja, conforme o ditado cubano, quando o camponês vê, tem fé.

Entre os princípios desenvolvidos pelo MACAC para a territorialização da agroecologia, destacam-se (Fernandes \& Barbosa, 2020): 1. Começar devagar e pequeno; 2. Limitar a introdução de tecnologia; 3. Alcançar resultado rápido e visível; 4. Experimentar em pequena escala; 5. Desenvolver um efeito multiplicador. Ao contrário de uma lógica de produção em larga escala e de monocultivo, tais princípios visam fortalecer processos duradouros, de 
forma diversificada, orgânica, em intrínseca relação com a dimensão comunitária das comunidades e de seus processos sociais e políticos.

Embora a agroecologia não se baseie em modelos ou receitas que possam ser cegamente copiados e transferidos de uma realidade para outra, o conjunto de elementos presentes na Metodologia $\mathrm{CaC}$ em Cuba, associados à participação ativa das famílias camponesas, a uma pedagogia horizontal, um desenho intencionado e organicidade, oferecem importantes princípios para processos nascentes em outros lugares (Rosset, 2015). E, em particular, para pensar o papel das escolas camponesas e das escolas do campo na territorialização da agroecologia (Barbosa \& Rosset, 2017a, 2017b; Caldart, 2017; Rosset et al., 2019). Rosset (2017, p. 90-91) propõe que, no caso do Brasil e do MST, as escolas do campo nos assentamentos e comunidades poderiam assumir a função de facilitação territorial:

O maior desafio é pensar como as Escolas do Campo poderiam funcionar como eixos de ação nos processos territoriais para elevar a escala da Agroecologia. Temos escolas do campo em todos os níveis: na Educação Básica, no Ensino Fundamental e no Ensino Médio, além das escolas e parcerias para a Educação Técnica e a Educação Superior... O desafio é o de conseguir que uma escola..., além de formar aos jovens como facilitadores de processos, se torne o epicentro de um processo ao estilo de $\mathrm{CaC}$ no seu território. A própria escola pode identificar aos camponeses(as) mais expertos em diferentes práticas agroecológicas e mobilizá-los como professores para os alunos, usando suas terras como salas de aula. A escola pode treinar estes camponeses(as) para que sejam promotores em um processo de $\mathrm{CaC}$, fornecendo-lhes ferramentas pedagógicas para melhor transmitir seus conhecimentos para outros camponeses. Finalmente, os educandos serão formados para ser os futuros promotores, facilitadores e coordenadores dos processos de $\mathrm{CaC}$ em suas comunidades e territórios (Rosset, 2017, p. 91).

Ao incorporarmos a agroecologia como uma dimensão formativa no processo pedagógico impulsionado pelas escolas do campo, fortalecemos a articulação de um diálogo horizontal entre conhecimentos - camponês e técnico-científico - na abordagem dos fenômenos da natureza, na compreensão histórica da ofensiva do capitalismo e suas interfaces no desequilíbrio da relação homem-natureza e, sobretudo, na apreensão do papel histórico do campesinato, da agricultura familiar camponesa e seu vínculo com a defesa do território e da reforma agrária popular. Além disso, a integração da agroecologia à base formativa das escolas do campo garante uma perspectiva de formação para a desalienação (Caldart, 2017) em relação à forma histórica de despojo territorial provocada pelo capitalismo, ao tempo que garante a ruptura epistemológica e ontológica na formação das futuras gerações, ao dar ênfase à valorização do conhecimento camponês e no reestabelecimento de seu vínculo com o território e o tecido comunitário que são parte constitutiva dos assentamentos e comunidades (Rosset, 2017; Barbosa \& Rosset, 2017a; Barbosa, 2019).

Em termos de uma territorialização da agroecologia, a inserção das escolas do campo e de escolas de formação como promotores responde a uma estratégia de conformação de "assentamentos agroecológicos" (Ribeiro et. al., 2017a, 2017b), ao tempo que reafirma a necessidade de formação de um sujeito histórico-político, de um método e de um projeto político para garantir a agroecologia enquanto processo político que contribui à luta do campesinato para a emancipação humana (Barbosa \& Rosset, 2017b). 


\section{Camponês/a a Camponês/a: recuperação de conhecimento $e$ descolonização epistêmica}

Mais do que implantar práticas agroecológicas exógenas para resolver problemas locais de produção, a Metodologia $\mathrm{CaC}$ trabalha para recuperar e socializar o conhecimento dos camponeses e camponesas sobre como produzir em um determinado bioma e território. Antes da modernização agrícola e da Revolução Verde, os camponeses e indígenas eram capazes de produzir alimentos em quase todos os territórios do mundo (Shiva, 2003; Lazzari \& Souza, 2017; Rosset \& Altieri, 2017). As epistemes e sabedorias coletivas dos territórios camponeses sofreram uma colonização forçada durante a Revolução Verde, pois os métodos da agricultura industrial (monocultura, agrotóxicos, fertilizantes químicos, sementes comerciais, compra de ração animal etc.) foram impostos tanto pelos pacotes produtivos das empresas de insumos agrícolas como pela extensão rural e a assistência técnica (Freire, 1973). O uso dessas tecnologias era exigido para ter acesso ao crédito e para participar de projetos.

Os camponeses e camponesas foram instruídos, de inúmeras maneiras, tanto explícitas quanto implícitas, a introjetarem que seus conhecimentos e práticas agrícolas eram antiquados, primitivos, não produtivos. Esse processo os educou a sentirem-se inferiores e a se envergonharem. Essa mediação pedagógica tinha o intuito de educá-los para ignorar, tanto quanto possível, seus próprios conhecimentos, e para respeitar e buscar o conhecimento de "expertos" - técnicos, agrônomos, pesquisadores, vendedores de pesticidas, intermediários - sempre que surgisse um problema de produção. O resultado de muitas décadas deste processo pedagógico foi que os velhos conhecimentos e formas de agricultura em cada território foram esquecidos por muitos camponeses, e/ou não foram totalmente transmitidos às gerações seguintes. As variedades, as sementes e a raças de gado crioulas foram praticamente perdidas, assim como as espécies locais de plantas que uma vez serviram como forragem animal. As antigas formas de agricultura em habitats secos foram largamente abandonadas, pois a agricultura passou a depender de irrigação moderna dispendiosa. Muitas pessoas até esqueceram que a agricultura sem crédito foi uma vez a norma.

Conhecimento, sabedorias, sementes e raças foram atomizados, fragmentados, pulverizados, de tal forma que ninguém se lembraria de tudo, mas em quase todos os territórios camponeses ainda existe aquela "velha camponesa" que ainda tem algumas variedades de sementes crioulas, aquele "velho louco" que ainda tem árvores frutíferas tradicionais, e outra família isolada que ainda usa espécies tradicionais de forragem para seus animais, etc. Embora este conhecimento e recursos ainda existam em sua forma fragmentada, isto normalmente é, em grande parte, invisibilizado nos níveis comunitário e territorial. Entretanto, formam o acervo de conhecimentos, práticas agrícolas, sementes, raças de animais, espécies de forragem etc., sobre os quais a Metodologia $\mathrm{CaC}$ trabalha. Nesse sentido, a Metodologia $\mathrm{CaC}$ articula uma ampla rede sobre um território ou comunidade, para descobrir e "capturar" esse conhecimento atomizado, e ressocializá-lo, de modo que ele possa mais uma vez se tornar um conhecimento coletivo, articulado em sua totalidade, de todas as famílias camponesas, em vez de ser dividido entre elas em pequenos pedaços. Em essência, 
um processo bem-sucedido de $\mathrm{CaC}$ pode ser visto como uma "descolonização epistêmica" de um território camponês, no sentido de uma recuperação e valorização dos conhecimentos ancestrais que permitem uma coexistência com o território.

Conforme formalizado em Cuba e em outros países, a Metodologia $\mathrm{CaC}$ consiste em princípios específicos e passos metodológicos, que são detalhados em várias publicações (Machín Sosa et al., 2012; Abreu \& Alonzo, 2018; MST-CE, 2019). Um dos primeiros passos, que é crucial para criar as condições para a descolonização do conhecimento, é o que os cubanos chamaram de "O Método de Banes” (Machín Sosa et al., 2012), e que no Brasil é denominado de "mapeamento" (Abreu \& Alonzo, 2018) ou de "inventário" de práticas e saberes (MST-CE, 2019). A realização do inventário requer uma equipe de facilitação, capaz de criar e aplicar um questionário a todas as famílias, pedindo-lhes que façam uma lista detalhada de todas as práticas "possivelmente agroecológicas" que elas realizam. Os resultados do questionário são organizados em uma tabela das famílias, mostrando quais práticas são utilizadas e por quais famílias. Com base nestas informações básicas, as etapas seguintes envolvem a organização de visitas de intercâmbio para famílias com problemas particulares de produção conhecerem aquelas famílias que já praticam soluções agroecológicas para estes problemas. Por exemplo, famílias com falta de ração para seus animais visitariam uma família que está usando, de forma bem-sucedida, espécies tradicionais de forragem, em vez de comprar ração animal comercial. As famílias anfitriãs oferecem oficinas sobre como utilizar suas práticas (Machín Sosa et al., 2012; MST-CE, 2019).

Ao dar-se a conhecer o resultado do Inventário das Práticas Agroecológicas, as famílias se deparam com um conjunto de conhecimentos de base agroecológica por elas mantidos historicamente, porém não reconhecidos. Esta “descoberta" pode ser um passo fundamental para uma descolonização epistêmica do território, no sentido de recuperar e visibilizar o que revelam essas práticas agroecológicas em termos de expressão de outro paradigma de concepção do território, pautado em outras bases epistêmicas e ontológicas, e sua relação com os princípios da agroecologia. Adentraremos na experiência do Assentamento Santana para analisarmos o papel do Inventário das Práticas Agroecológicas no processo de territorialização da agroecologia.

\section{Antecedentes do Assentamento Santana ${ }^{1}$ e da agricultura camponesa}

O Assentamento Santana ${ }^{2}$ está localizado na Região dos Inhamuns, no município de Monsenhor Tabosa, sertão cearense. Essa região é conhecida por uma histórica resistência camponesa que data da década de 1960, mais precisamente a partir de 1964, ano de implantação da ditadura militar no país. Nesse período, é criada a Diocese de Crateús, outro

\footnotetext{
${ }^{1}$ Além das fontes citadas nesta seção, as informações históricas do assentamento são recuperadas por duas autoras do artigo, que são assentadas no Assentamento Santana.

${ }^{2} \mathrm{O}$ assentamento é organizado por setores de comercialização, transporte, agricultura, pecuária, infraestrutura, agroindústria que representa a apicultura. Há, ainda, o setor de desenvolvimento social, representado pela educação, saúde, comunicação e cultura.
} 
município da região, tendo por primeiro bispo Dom Antônio Batista Fragoso 3 , conhecido como Dom Fragoso, cuja proposta de atuação era fortemente marcada por uma tradição da educação popular e baseada nos princípios da Teologia da Libertação.

Conforme Barbosa (2017), as pastorais dos municípios da Região de Crateús e Inhamuns buscavam consolidar uma formação religiosa inspirada em tais princípios e desenvolviam uma formação de base junto às comunidades rurais e organizações de trabalhadores do campo, sempre no horizonte da valorização sociocultural e política do semiárido. As práticas religiosas e sociais destinavam-se à formação política e à organização de agricultores e seus familiares, tendo como resultado direto o engajamento da Igreja em espaços de articulação político-social expressivos, tais como sindicatos, associações, grupos pastorais, dentre outras entidades de luta pela garantia do trabalho na e pela terra.

No caso da fazenda onde viviam as famílias nesse período, era utilizada, basicamente, para a criação de gado de forma extensiva. $\mathrm{Na}$ fazenda residiam treze "moradores" que, de forma conjunta com mais 41 famílias da região, faziam o plantio de culturas anuais no sistema de "renda", onde a maior parte da produção era destinada ao patrão. Além disso, antes de terminarem a colheita, o gado era solto em suas plantações, uma estratégia das oligarquias locais de aniquilarem a produção de subsistência das famílias camponesas.

Nesses antecedentes históricos, a agricultura praticada pelos "moradores" e pelas famílias do entorno era para consumo familiar e pagamento da renda da terra ao patrão. Não havia uso de técnica de conservação dos recursos naturais. Para limpeza da área cultivada, os agricultores faziam a broca técnica caracterizada pela derrubada das árvores com foices - e, após a retirada da madeira, seguia-se com a queima. A partir dessa realidade vivenciada nas terras do patrão, as famílias Lourenço e Machado e demais trabalhadores da região começaram a se organizar e a denunciar as várias irregularidades existentes na propriedade, sobretudo a forma desumana como os trabalhadores eram tratados.

A participação ativa das CEBs, mediadas pelo Bispo Dom Fragoso, contribuíram no processo formativo das famílias, que foram adquirindo a consciência crítica em torno da questão agrária, da luta pela reforma agrária e por melhores condições de vida no campo. É uma experiência que se iniciou em 1986, fruto da luta para criar condições concretas de superação da pobreza em que viviam os trabalhadores e trabalhadoras rurais. Desse modo, após a conquista da terra, as famílias assentadas conseguiram transformá-la em espaço fecundo de vida, história e realizações. Hoje, o assentamento é composto por 100 famílias, com uma população de 400 pessoas que vivem coletivamente na terra e adota um sistema misto de produção. Vale ressaltar que as famílias assentadas se reconhecem como camponeses, ao tempo que também constroem sua identidade como classe trabalhadora do campo, uma vez que a relação com o trabalho é mediada pela produção em sua terra.

Logo após a desapropriação da área, as famílias perceberam que a terra de Santana não era apropriada para exploração individual, pois uma grande parte dos solos apresentavam baixo índice de produtividade, eram rasos e pouco férteis. Além

${ }^{3}$ Dom Fragoso foi Bispo da Arquidiocese de Crateús de 1964-1998. 
disso, o próprio processo organizativo das famílias em condição de assentamento criou as condições sociais para a decisão de não parcelar a propriedade, mas desenvolver o uso, a posse da terra e os trabalhos de forma coletiva (Araújo, 2006). Essas decisões foram tomadas com a participação de todas as famílias. Em 1992, o assentamento se vincula ao MST, em um contexto histórico de conformação do Movimento no Ceará.

Nos seus primeiros oito anos (1987-1994), o Assentamento Santana vivenciou um intenso processo de fortalecimento orgânico das famílias, em que os assuntos inerentes ao assentamento eram discutidos somente de forma coletiva: posse e uso da terra, produção agropecuária, comercialização e gestão, entre outros. Do mesmo modo, todos os trabalhos eram desenvolvidos de forma coletiva. A partir de 1995, o assentamento começou a desenvolver uma produção mista, isto é, de base coletiva e familiar (Araújo, 2006).

Ao longo dos anos, o Assentamento Santana vem refletindo sobre os problemas produtivos preexistentes, com o intuito de minimizar os danos causados ao solo e ao bioma caatinga, devido à expansão agropecuária, à caça predatória e longos períodos de seca, o que ocasionou erosão genética do solo e cultural.

Os alimentos que as famílias produzem são provenientes da agricultura: roçados, quintais produtivos, cisternas de enxurrada ${ }^{4}$, pecuária, açudes (vazantes) e apicultura, a partir de um sistema misto de produção. A pecuária é uma das atividades produtivas de destaque tanto para consumo como para a renda familiar. A produção é utilizada para o consumo e o excedente é comercializado. Nos últimos anos, as atividades agrícolas e pecuárias tiveram sua produção reduzida devido à seca severa que perdura no Ceará, sobretudo na Região dos Inhamuns e Crateús, que já se prolonga por quase uma década. Há outros desafios, dentre eles, o de minimizar o desmatamento, uma causa importante para deixar o solo desprotegido. Com o passar dos anos, o solo tem ficado suscetível à compactação e salinização. O pastoreio animal tem diminuído a cobertura vegetal, aprofundando a erosão, a redução dos nutrientes do solo, além de sua compactação.

O uso de agrotóxicos é baixo no assentamento. É notável que, entre as famílias, há uma boa compreensão em relação à produção de alimentos saudáveis, a partir de processos agroecológicos que preservem o meio ambiente na perspectiva da soberania alimentar, uma reflexão construída organicamente nos processos de luta e defesa do território articulados pelo MST. Os desmatamentos e as queimadas vêm diminuindo gradativamente ao longo dos anos. O número de pessoas que adota esse método é bem reduzido, muito embora ainda é preocupante. Consideramos urgente cuidarmos melhor do solo, pois " $[\ldots]$ o alimento, a água e o oxigênio vêm do solo das plantas que ele produz" (Primavesi, 2016, p.10).

Nesse sentido, a experiência de vários agricultores e agricultoras demonstra que, com práticas agroecológicas, é possível conviver com a região semiárida. As estratégias vão desde a estocagem familiar e coletiva de sementes crioulas e nativas, estocagem de forragem para os animais, até o armazenamento de água da chuva em cisternas,

\footnotetext{
${ }^{4}$ Das cem (100) famílias residentes no Assentamento Santana, oitenta e sete (87) possuem cisterna de placa com a capacidade de 16 mil litros d'água e vinte e duas (22) destas famílias já possuem as cisternas de enxurradas, com a capacidade de 52 mil litros.
} 
açudes e barragens, entre outras. Em que pesem essas estratégias de convivência com o semiárido, constatamos durante o processo de implantação da Metodologia $\mathrm{CaC}$ a seguinte questão: as famílias camponesas do Assentamento Santana associam essas experiências às práticas agroecológicas?

\section{Metodologia "De Camponês/a a}

\section{Camponês/a - do Inventário e do}

Diagnóstico Rápido Participativo à identificação de promotores com boas práticas agroecológicas

Em 2018, realizamos no Centro de Formação Frei Humberto o "Seminário sobre a Metodologia Camponês a Camponês para levar a Agroecologia a Escala Territorial" e a "Oficina Intensiva de Planejamento do processo piloto de Camponês a Camponês na região do Assentamento Santana". Com a presença da ANAP, principal organização camponesa de Cuba e impulsionadora da Metodologia $\mathrm{CaC}$ na região latino-americana e caribenha, este foi o passo inicial para a implementação da Metodologia $\mathrm{CaC}$ no Assentamento Santana. O processo ocorreu de forma dinâmica, com a participação da LVC, da Universidade Estadual do Ceará (UECE) e, sobretudo, com a incorporação da participação direta das famílias assentadas, da assembleia do assentamento, do Setor de Educação e do Setor Produção, da Brigada Dom Fragoso do MST, além de educadores(as) e educandos(as) da Escola de Ensino Médio do Campo Florestan Fernandes, uma escola do campo localizada no assentamento.

A sistematização do processo de implementação da Metodologia $\mathrm{CaC}$ é uma importante etapa no acompanhamento do escalonamento e territorialização da agroecologia no Assentamento Santana e região. Nossa intenção é evidenciar a dinâmica criativa no processo de construção do conhecimento agroecológico, bem como de uma pedagogia camponesa agroecológica, desenvolvida pelas famílias camponesas inseridas num movimento participativo de defesa do território camponês e de construção coletiva e socialização de saberes. $\mathrm{O}$ primeiro passo foi o levantamento do Inventário das Práticas Agroecológicas já desenvolvidas pelas famílias camponesas, baseado na "Experiência de Banes", feito por meio de formulário elaborado para o controle das práticas e saberes agroecológicos. Esse inventário nos permitiu identificar mais de 40 práticas agroecológicas desenvolvidas para a convivência com o semiárido e que sequer eram reconhecidas como agroecológicas pelas próprias famílias.

Na Assembleia Geral do Assentamento foi socializado o resultado do Inventário das Práticas Agroecológicas, que se configura no processo de construção do conhecimento agroecológico interligado por práticas de camponeses(as) agricultores(as) assentados(as), que deverão partilhar seus saberes mediado pela Metodologia CaC. A implementação da metodologia incluiu o intercâmbio entre as famílias, além da incorporação do campo experimental da Escola do Campo Florestan Fernandes como um dos espaços de transição agroecológica. Outro elemento a destacar no levantamento do inventário foi a incorporação de outros dois assentamentos, a saber, o Assentamento Orange e o Assentamento Bargado, totalizando a participação de 114 famílias camponesas e 170 estudantes da Escola de Ensino Médio do Campo Florestan Fernandes, conforme a Tabela 1 a seguir: 
TABELA 1 - Assentamentos e número de famílias que participaram do processo ${ }^{5}$.

\begin{tabular}{|c|c|c|c|c|c|c|}
\hline Município & Assentamento & $\begin{array}{l}\text { Ano da } \\
\text { criação }\end{array}$ & Famílias & $\begin{array}{c}\text { Famílias o processo } \\
\text { de Camponês a } \\
\text { Camponês }\end{array}$ & $\begin{array}{c}\text { Tamanho da } \\
\text { propriedade (posse } \\
\text { e uso coletivo) }\end{array}$ & Recursos hídricos \\
\hline Monsenhor Tabosa & Assentamento Santana & 1986 & 100 & 100 & $3.313 \mathrm{hac}$ & $\begin{array}{l}06 \text { açudes } \\
02 \text { poços artesianos } \\
124 \text { cisternas }\end{array}$ \\
\hline Monsenhor Tabosa & Assentamento Bargado & 1992 & 44 & 01 & 830 hac & $\begin{array}{l}02 \text { açudes } \\
01 \text { poço artesiano }\end{array}$ \\
\hline Tamboril & Assentamento Orange & 2010 & 13 & 13 & 882 hac & $\begin{array}{l}01 \text { açude } \\
01 \text { poço artesiano } \\
12 \text { cisternas } \\
\end{array}$ \\
\hline
\end{tabular}

FONTE: Arquivo do projeto.

\section{É possível anunciar que encontramos nas} famílias assentadas o desejo, a coragem, o compromisso com a terra e com a vida, além de práticas viáveis para permanecer no campo. A preservação da identidade camponesa, a defesa de um território autônomo, e de consolidação de uma autonomia camponesa vinculada à educação e à agroecologia, em defesa do território e dos bens comuns, tem sido marcante e histórica na luta por terra, pão e liberdade dessas famílias. Nesse sentido, o Inventário das Práticas Agroecológicas acompanhou outros passos metodológicos para a implantação do processo da Metodologia "De Camponês a Camponês".

\subsection{Passo 1}

Iniciamos com um processo de integração e formação da equipe que iria coordenar a Metodologia $\mathrm{CaC}$, com a participação e gestão coletiva do Assentamento Santana e Escolas do Campo, Brigada Dom Fragoso, Setor de Produção, Setor de Educação e membros da coordenação do projeto no âmbito estadual. A equipe é composta de seis (06) pessoas, sendo 03 educadores da Escola de Ensino Médio do Campo Florestan Fernandes, 01 dirigente da Brigada Dom Fragoso e 02 pessoas do Setor de Produção do MST/CE. A equipe de trabalho vive no cotidiano do território e atua em atividades que estão ligadas à Agroecologia, Educação do

\footnotetext{
${ }^{5}$ Esse quadro se baseia no formato desenvolvido pelos autores De Siqueira, P. Z. R. et al. A experiência da metodologia camponês a camponês em territórios de identidade rural no Nordeste do Brasil. In: Embrapa Tabuleiros Costeiros-Artigo em anais de congresso (ALICE). In: CONGRESSO DA ASSOCIAÇÃO LATINO AMERICANA, 9., 2014, México. Sociedades rurais latino americanas: diversidades, contrastes e alternativas: anais. México: ALASRU, 2014.
} 
Campo e Reforma Agrária Popular, portanto, conhecem as famílias assentadas camponesas e conseguem identificar aquelas que têm referências agroecológicas. A partir da realização de um conjunto de reuniões, formulou-se o questionário para o levantamento do Inventário das Práticas Agroecológicas e sua aplicação junto às famílias assentadas. Para isso, estabeleceu-se um roteiro elaborado no coletivo, com o intuito de conduzir o processo com organicidade. A proposição foi construída para orientar no levantamento dos dados, sugerindo questões relacionadas a determinadas práticas, com destaque: práticas de conservação da água e do solo, práticas edáficas, vegetativas, mecânicas, características pessoais (promotores), características pessoais (facilitadores)

\subsection{Passo 2}

Aplicações dos questionários: o levantamento do Inventário das Práticas Agroecológicas com as famílias foi realizado por um coletivo composto por 20 pessoas. Neste sentido, utilizamos a metodologia do trabalho em grupo, a partir do pressuposto de que quanto mais pessoas se apropriem do processo, maiores as possibilidades de êxito e sustentabilidade do trabalho no processo de implantação da Metodologia "De Camponês a Camponês".

\subsection{Passo 3}

Sistematização dos dados e apresentação qualitativa e quantitativa na Assembleia Geral do Assentamento Santana. O resultado do Inventário das Práticas Agroecológicas se configura no processo de construção do conhecimento agroecológico interligado por práticas de agricultores e agricultoras assentados/as, que deverão partilhar seus saberes mediado pela Metodologia "De Camponês a Camponês". Nessa ocasião, também foram apresentadas as dificuldades encontradas, sobretudo com o manejo do solo e da água. A partir da apresentação dos resultados sistematizados, dos debates e diálogos estabelecidos, elegeu-se no grupo quais seriam as práticas que deveriam ser recuperadas e multiplicadas, com o intuito de fortalecer o processo de territorialização da agroecologia e contribuir na viabilização e conservação do solo e da água no território do semiárido. Entre elas, destacam-se: raleamento de arbustos; rebaixamento; enleiramento de garranchos em níveis; plantio de espécies nativas; plantio em áleas; cobertura morta. Essas práticas são fundamentais para o manejo e o cuidado do solo. É uma tecnologia muito simples, que compreende um conjunto de práticas que, quando usadas racional e coletivamente, podem permitir uma alta produtividade das culturas a baixos custos.

\subsection{Passo 4}

Seleção de dez famílias que se identificaram com o perfil de promotor(a), sendo: 01 do Assentamento Bargado, 04 do Assentamento Orange e 04 do Assentamento Santana (01 é a Escola de Ensino Médio do Campo Florestan Fernandes). Em seguida, aconteceu diversas reuniões para elaboração e organização do Diagnóstico Rápido Participativo (DRP) de visita às famílias, mediado pela equipe de coordenação. Ainda compôs essa fase de sistematização do DRP a reunião para definir os promotores que iniciariam os intercâmbios e a 
socialização de experiência e saberes com as demais famílias. Dentre as etapas do processo, foram planejadas e elaborado coletivamente o roteiro das oficinas ${ }^{6}$ de intercâmbio de boas práticas, que auxiliou na gestão e organização das atividades. Essa organização conduziu a bons resultados na realização das oficinas agroecológicas mediada pelo saber camponês.

Assim como o Inventário das Práticas Agroecológicas nos revelou um conjunto de práticas com potencial agroecológico, o DRP nos permitiu identificar problemas produtivos, especialmente aqueles relacionados à erosão do solo, salinidade e o manejo do bioma caatinga, secas constantes, entre outros. ${ }^{7}$ Outro problema identificado pelo DRP é a dependência do mercado para ração animal. Entretanto, constatamos várias iniciativas espalhadas nas diversas famílias, que expressam conhecimentos dos camponeses e camponesas e que são usados para lidar com os problemas identificados, conforme A Tabela 2 a seguir:

Diante do mapeamento das práticas agroecológicas e de convivência com o semiárido, bem como dos problemas e potencialidades produtivas no Assentamento Santana e região, alguns pontos sistematizados na tabela acima chamam a atenção, no sentido de serem enfrentados e superados coletivamente. É preciso avançar em técnicas que ajudem as águas a penetrar na terra. É urgente a tarefa de preparar a área para o plantio, de forma que agrida o mínimo possível o solo, evitando-se a queimada e utilizando técnicas alternativas que contribuam significativamente para ampliar os conhecimentos e desenvolver a consciência críticas dos camponeses e camponesas para a preservação e o cuidado com solo, sendo que este é um organismo vivo. Dessa forma, acreditamos que é possível expandir o trabalho em agroecologia horizontalmente, baseado no diálogo,

TABELA 2 - Questões sobre conservação do solo e da água

\begin{tabular}{lcc}
\hline Perguntas & $\begin{array}{c}\text { \% das famílias que } \\
\text { responderam -Sim }\end{array}$ & $\begin{array}{c}\text { \% das famílias que } \\
\text { responderam -Não }\end{array}$ \\
\hline Você faz Compostagem? & $2 \%$ & $98 \%$ \\
\hline Você faz Rotação de Cultivos? & $54 \%$ & $46 \%$ \\
\hline Você faz Cultivos Consorciados? & $76 \%$ & $24 \%$ \\
\hline Você faz Policulturas? & $94 \%$ & $6 \%$ \\
\hline Você faz Adubação orgânica com esterco? & $50 \%$ & $30 \%$ \\
\hline Você faz curva de nível? & $76 \%$ & $44 \%$ \\
\hline Você faz o uso de tração animal para trabalhar na terra? & $72 \%$ & $28 \%$ \\
\hline $\begin{array}{l}\text { Você faz controle de erosão através de cordões de pedra e } \\
\text { terraços de contenção? }\end{array}$ & $2 \%$ & $98 \%$ \\
\hline
\end{tabular}

FONTE: Arquivo do projeto.

${ }^{6}$ A mobilização da Oficina aconteceu diariamente no Programa de Rádio Educação em Foco, em assembleias e convite individual para cada participante. As oficinas, além de ser um espaço de formação e intercâmbio, se tornaram um momento de festejo e partilha de alimentos, sonhos e esperança.

${ }^{7} \mathrm{O}$ quadro com poucas chuvas se agravou e estamos com quase uma década com secas constantes na região. 
intercâmbios, experimentos, tendo por base uma metodologia que tem como princípio cultivar, resgatar e compartilhar conhecimentos necessários para o bem viver no semiárido.

A partir das reflexões e debates com as famílias, é notório a importância de uma estratégia metodológica que potencialize a convivência com o semiárido. Assim, avançar no manejo do bioma caatinga é um dos nossos horizontes com a Metodologia do $\mathrm{CaC}$. O esforço precisa ser coletivo e as famílias necessitam estar predispostas a mudanças, conscientes que as práticas de conservação do solo e da água são importantes para alcançar êxito e rentabilidade no controle da erosão do solo, genética, cultural, etc. Assim, percebemos a necessidade de um plano de manejo do solo e captação de água de acordo com sua capacidade de uso, considerando o bioma caatinga, a agroecologia e a convivência com o semiárido. Até o momento, ainda é necessário ampliarmos os reservatórios de captação de água com práticas de convivência com o semiárido conforme o quadro acima. No Assentamento Santana e região, as famílias assentadas têm acesso a cisterna de enxurrada ${ }^{8}$, uma tecnologia social com capacidade para acumular 52 mil litros de água. Junto à cisterna ainda foram construídos dois canteiros.

Aágua armazenada durante o período chuvoso é utilizada para o cultivo das hortaliças e frutíferas, melhorando consideravelmente a qualidade da alimentação familiar. Isso comprova a importância das tecnologias sociais de captação de água na região semiárida onde as chuvas, além de irregulares, ocorrem em poucos meses com média anual de 750 milímetros. Sugerimos potencializar a produção com pouca água (atividades como: apicultura, caprinocultura e a técnica de gotejamento). Um desafio que temos é: como produzir com água salina? E o que produzir? Essas indagações foram citadas na assembleia de apresentação dos resultados do diagnóstico. Aqui identificamos a centralidade pedagógica das escolas do campo e das instituições que lidam e pesquisam tecnologias de convivência com o semiárido, no sentido de implementar tecnologias sociais para melhorar a produtividade do trabalho e das áreas produtivas das famílias.

Um elemento fundamental no processo de territorialização agroecológica é o nível de organicidade das famílias. De acordo com os resultados encontrados, praticamente todas as famílias estão inseridas em associações e cooperativas.

É possível e necessário que um novo paradigma para o campo se faça presente na concepção de mundo camponesa. Paradigma esse que contemple o camponês como sujeito social, organizado nas mais diversas formas de cooperação e com crescente e apropriado desenvolvimento dos seus meios de trabalho para potencializar a terra e o trabalho. Uma outra utopia, construída por eles próprios nos seus que-saberes e que-fazeres socializados, na qual se afirme a autonomia e a acumulação camponesas. E que contribua efetivamente para que os camponeses deixem de ser "os quase sempre ignorados" (Carvalho, 2010, p. 12).

A cooperação entre as famílias assentadas do Assentamento Santana e região é uma alternativa sábia para vencer as adversidades que surgem

8 É uma tecnologia social construída por meio de convênios firmados entre o Ministério de Desenvolvimento Social - MDS e a Articulação do Semiárido - ASA, inseridas nas políticas do Programa Um Milhão de Cisternas - P1MC e do Programa Uma Terra de Duas Águas - P1+2. 
cotidianamente. Conforme as entrevistas realizadas, todas estão inseridas no sistema de cooperação. Veja a Tabela 3 a seguir:

O cooperativismo ${ }^{9}$ facilita o uso racional de equipamentos, racionaliza as atividades póscolheita e promove um escoamento eficiente dos produtos, um processo observado no Assentamento Santana.

Observamos que as famílias assentadas entrevistadas produzem, principalmente, para a segurança alimentar das famílias, trocas e doações; entre estas famílias, várias vendem seus produtos para programas governamentais, tais como o Programa de Aquisição de Alimentos (PAA) e o Programa Nacional de Alimentação Escolar (PNAE); outros vendem para feiras da agricultura familiar e venda direta ao consumidor. Assim, contribui eficazmente para a valorização da agricultura familiar camponesa e do campesinato mediante a geração de renda e a produção de alimentos que geram saúde e vida.
Ainda como espaço de comercialização, troca de produtos, socialização de experiências e saberes, as famílias organizam, anualmente, feiras da agricultura familiar no Assentamento Santana, com a participação das comunidades e de outros assentamentos da região. O processo de análise foi acompanhando de um exercício de identificação dos promotores/multiplicadores que tem a missão de semear e multiplicar conhecimentos agroecológicos no território Inhamus e Crateús.

No processo de implementação da Metodologia $\mathrm{CaC}$, a Equipe de Coordenação organiza e promove, junto às famílias assentadas com práticas agroecológicas, uma série de formações, oficinas e intercâmbios, com o intuito de promover um espaço de compartilhamento de conhecimentos, vivências e investigações em torno à estas práticas. Constitui um espaço de diálogo interligado aos princípios da Metodologia $\mathrm{CaC}$, em que participam as famílias camponesas, inspiradas no princípio

TABELA 3 - Características pessoais (Promotores)

\begin{tabular}{lcc}
\hline Perguntas & $\begin{array}{c}\text { \% das famílias que } \\
\text { responderam -Sim }\end{array}$ & $\begin{array}{c}\text { \% das famílias que } \\
\text { responderam -Não }\end{array}$ \\
\hline Você participa de associações e cooperativas? & $100 \%$ & $0 \%$ \\
\hline $\begin{array}{l}\text { Você receberia outros agricultores em sua roça para conhecer } \\
\text { suas experiências de cultivo? }\end{array}$ & $86 \%$ & $14 \%$ \\
\hline $\begin{array}{l}\text { Você se considera uma pessoa aberta ao diálogo e às ideias de } \\
\text { outras pessoas? }\end{array}$ & $50 \%$ & $50 \%$ \\
\hline $\begin{array}{l}\text { Você está disposto a ir até outras propriedades para aprender } \\
\text { coisas novas com outros agricultores? }\end{array}$ & $69 \%$ & $31 \%$ \\
\hline Você gosta de organizar atividades em sua comunidade? & $86 \%$ & $14 \%$ \\
\hline Você gosta de realizar trabalhos em grupo ou equipe? & $83 \%$ & $17 \%$ \\
\hline
\end{tabular}

FONTE: Arquivo do projeto.

${ }^{9}$ O Assentamento Santana dispõe de uma Cooperativa Agropecuária, potencialidade a ser explorada, pois na região todas as comunidades e assentamentos dispõem de associações. Assim, além de oportunizar o fortalecimento da cooperativa já existente, os agricultores familiares locais poderiam contar com amplo canal de comercialização e de abastecimento local e regional, resultando em uma melhor e maior competitividade para seus produtos. Dessa forma, observa-se a possibilidade de geração de renda. 


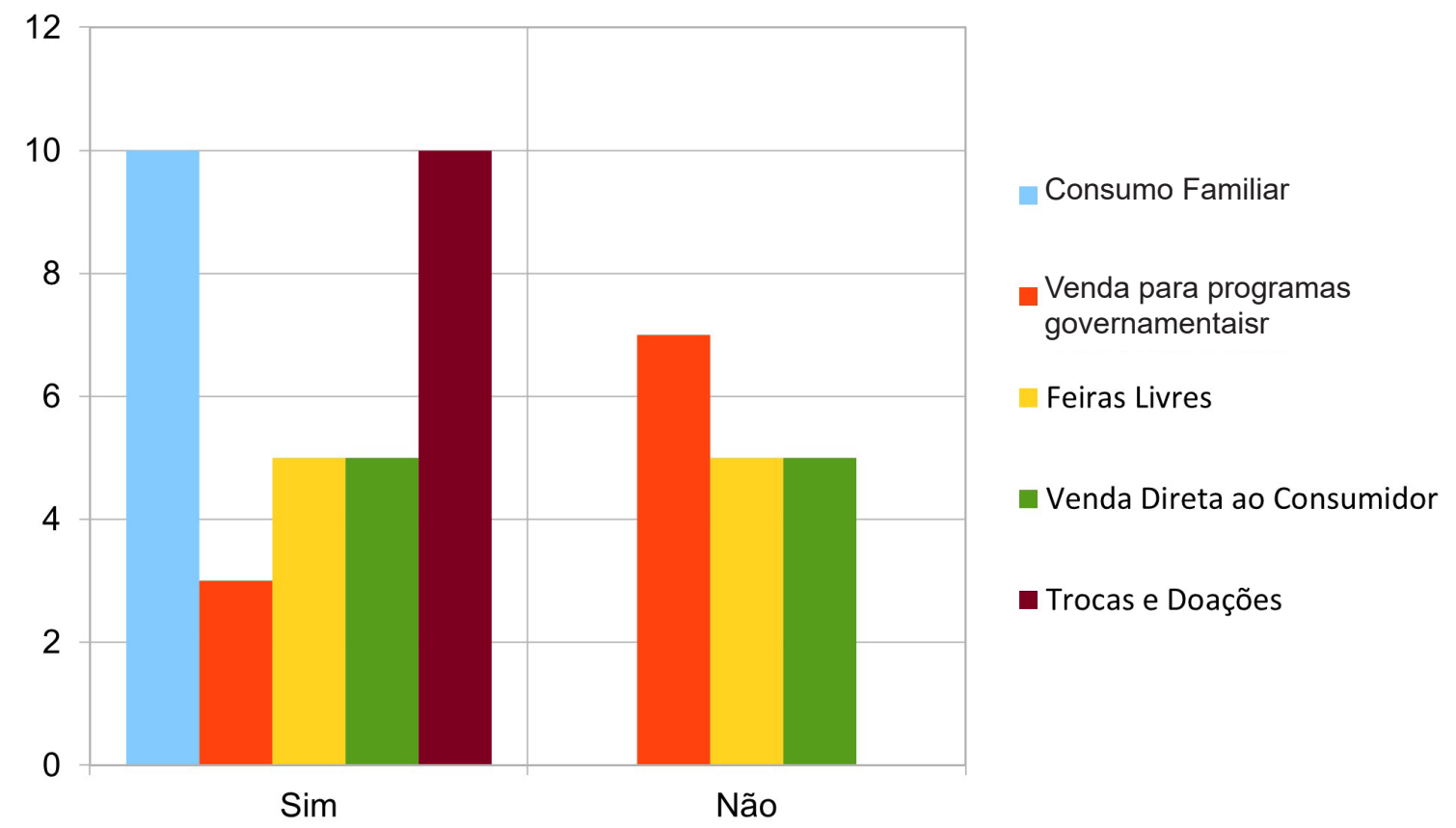

FIGURA 1 - Destino da produção dos promotores/as visitados/as. FONTE: Elaboração a partir do Diagnóstico Rápido Participativo.

cubano: "Quando o agricultor vê, ele acredita!". Esta é a proposição preliminar da metodologia social de difusão da Agroecologia "De Camponês a Camponês".

De acordo com a análise do perfil das famílias, identificamos, no primeiro momento, dez promotoras de três assentamentos. Essas famílias têm deixado o semiárido mais vivo com boas práticas agroecológicas. Nessa fase, visitamos os quintais produtivos, roças, criação de animais e plantio de suporte forrageiro, bem como o campo experimental da Escola do Campo Florestan Fernandes, dentre outros espaços. Durante as visitas nas roças, cada família teve a oportunidade de apresentar sua história de vida, sua experiência agroecológica e os problemas de produção que estão enfrentando. Segundo os relatos das famílias, apesar dos problemas produtivos da região, aprenderam que é preciso conviver com o semiárido. Segundo sua perspectiva, esse convívio é possível plantando plantas forrageiras, frutíferas e nativas, com a preparação da ração animal no tempo certo, para tê-la no momento de maior escassez, entre outras práticas. Em outros termos, estabelecer uma relação de trabalho com a terra de modo que respeite a resiliência ambiental. 
É nítido que, em todos os DRPs, as famílias citam o desejo de que seu trabalho com práticas agroecológicas seja visto e multiplicado por outras famílias assentadas, ou seja, que o esforço feito no presente se revele no futuro. Esforços, dedicação, coragem e zelo são alguns dos sentimentos designados ao quintal produtivo das famílias assentadas que, além de agricultores, são exemplos de camponeses que cuidam da vida, da terra e da natureza. A história dessas famílias e de tantas outras ajudaram a reforçar a importância da agroecologia como estratégia de convivência com o semiárido, segurança alimentar e da preservação do meio ambiente.

Trata-se, portanto, de um contexto privilegiado para as proposições de regaste das práticas ancestrais, intercâmbio e experimentos utilizando as vivências e dificuldades enfrentadas pelos sujeitos, tais como: estocagem de alimento humano, captação de água da chuva, recaatingamento, manejo da caatinga. Nessa direção, tanto a socialização do Inventário das Práticas Agroecológicas quanto a Metodologia $\mathrm{CaC}$ proporcionam uma transformação de consciência das famílias assentadas. Percebe-se que o Assentamento Santana apresenta condições favoráveis para o processo de transição agroecológica, tendo em vista o rico tecido social que confirma o potencial significativo de transformação da natureza do Assentamento e as contribuições direcionadas da escola ao processo consciente de transição.

\section{Revelações do Inventário das Práticas Agroecológicas: reflexões finais}

No início de nossa reflexão, argumentamos que o processo de consolidação do capitalismo no campo requereu de uma base subjetiva, marcada por uma colonização do conhecimento para garantir a imposição da racionalidade capitalista. O soterramento, a negação, o menosprezo, a invisibilização dos conhecimentos de base camponesa é parte intrínseca da mediação pedagógica exercida historicamente pelo capital, com a intenção de educar para a aceitação passiva do agronegócio no campo, em diferentes países.

Nessa direção, no âmbito da disputa hegemônica dos territórios, a agroecologia emerge como uma estratégia do campesinato na confrontação do capitalismo agrário. Entretanto, para que se assuma a agroecologia como princípio e projeto político, é imprescindível articular um processo educativo-pedagógico que conduza à descolonização desse conhecimento imposto historicamente e, em seu lugar, fortaleça as bases onto-epistêmicas de um paradigma que permita pensar e construir outra concepção de território e de reprodução social. Por isso, chegou-se à conclusão de que as organizações camponesas necessitam de metodologias libertadoras, que permitam às pessoas reconhecerem que são construtoras de um conhecimento, assumir o controle de seus processos produtivos e serem protagonistas de seu destino. Métodos que estimulem processos dinâmicos e criativos.

Da mesma forma, devem promover a capacidade de ação coletiva e de mobilização, necessárias tanto para a apropriação e transformação da produção, como para o desafio da luta política em defesa do território camponês. No método de $\mathrm{CaC}$, o sujeito do processo de territorialização da agroecologia é o camponês ou a camponesa, não o técnico. E este é o principal - ainda que não seja o único- segredo de seu êxito, pois, como se diz no 
campo: «o camponês acredita mais no que faz outro camponês, do que no que um técnico diz ».

No processo de territorialização da agroecologia do Assentamento Santana, o Inventário das Práticas Agroecológicas revelou um conjunto de elementos que expressam um processo de descolonização do conhecimento, conforme destacamos a seguir:

1. Desde que foi socializado o Inventário das Práticas Agroecológicas, os três assentamentos envolvidos passaram a valorizar seus conhecimentos como parte de uma memória ancestral camponesa presente em seus territórios. Esse reconhecimento se revela não só na vivência da Metodologia $\mathrm{CaC}$, mas em processos cotidianos, em que muitas famílias agora fotografam e filmam suas hortas, roçados e quintais produtivos e difundem nas redes sociais, como Instagram, Facebook, Whatsapp, ou ainda, em sites do MST-CE;

2. No processo de realização do Inventário das Práticas Agroecológicas e do DRP, as mulheres camponesas se perceberam como um sujeito central das práticas agroecológicas em seus quintais produtivos. É válido salientar que, antes, elas consideravam que apenas "ajudavam o marido". Mas o processo de territorialização agroecológica provocou um deslocamento de seu olhar, no sentido de reconhecerem seu papel numa abordagem agroecológica da produção, haja vista que as camponesas são guardiãs de um conhecimento ancestral que se revela em seus quintais produtivos. Nesse sentido, há um elemento inovador na experiência do Assentamento Santana, relacionada à mudança da nomenclatura da metodologia de territorialização da agroecologia, agora denominada Metodologia "De Camponesa a Camponês a Camponesa a Camponês";

3. Há uma disposição das famílias assentadas em dar continuidade à territorialização da agroecologia, com a ampliação e o aprofundamento das visitas de intercâmbio para as trocas de experiências da Metodologia "De Camponesa a Camponês a Camponesa a Camponês".

Finalmente, as revelações emanadas do Inventário de Práticas Agroecológicas propiciaram uma irradiação do processo de territorialização da agroecologia, sobretudo com a decisão do MST-Ce em expandir o processo em âmbito estadual. No momento em que finalizamos a escrita do presente artigo, o Movimento realiza o "Seminário de Territorialização da Agroecologia e Metodologia 'De Camponesa a Camponês a Camponesa a Camponês' nos Assentamentos de Reforma Agrária Popular do MST-Ce", com a incorporação de 14 territórios camponeses ao processo.

\section{Agradecimentos}

A presente pesquisa foi realizada com o apoio do C.S. Fund e do Center for de Study of the Americas (CENSA), nos Estados Unidos, com uma bolsa BPV da Fundação Cearense de Apoio ao Desenvolvimento Científico e Tecnológico (FUNCAP) concedida ao coautor do artigo, Peter Michael Rosset e com uma bolsa de produtividade acadêmica do Conselho Nacional de Desenvolvimento Científico e Tecnológico (CNPq) concedida à coautora Lia Pinheiro Barbosa. 


\section{Referências}

Abreu, P. H. B; Alonzo, H. G. A. Salutogênese Camponês a Camponês: uma metodologia para a promoção da saúde de populações expostas a agrotóxicos. Saúde em Debate, 42 (especial 4), 261-274, 2018.

Araújo, L. B. C. Sociabilidade no assentamento rural de Santana-CE: terra e trabalho na construção do ser social. Fortaleza, Tese (Doutorado em Educação Brasileira) - UFC, 2006.

Barbosa, L. P. A Jornada Universitária em Defesa da Reforma Agrária Popular nos sertões de Crateús-CE. In: Sampaio, A.; Oliveira, L. A.; Bastos, R. (Orgs.). À sombra das castanheiras. Luta camponesa: cultura, memória e história. Fortaleza: Plebeu Gabinete de Leitura Editorial, p. 62-75, 2017.

Barbosa, L. P. Paradigma Epistêmico do Campo e a construção do conhecimento na perspectiva dos movimentos indígenas e camponeses na América Latina. In: Santos, A. R. et al. (Orgs.). Educação e movimentos sociais. Análises e desafios. Jundiaí: Paco Editorial, p. 279-299, 2019.

Barbosa, L. P.; Rosset, P. M. Educação do campo e pedagogia camponesa agroecológica na América Latina: aportes da La Via Campesina e da CLOC. Educação e Sociedade, 38(140), 705-724, $2017 \mathrm{a}$.

Barbosa, L. P.; Rosset, P. M. Movimentos sociais e Educação do Campo na América Latina: aprendizagens de um percurso histórico. Revista Práxis Educacional, 13(26), 22-48, $2017 b$.

Batista, A. F. Consciência e territorialização contrahegemônica: Uma Análise das Políticas de Formação da Via Campesina América do Sul. São Paulo: Editora Unesp, 2014.

Caldart, R. S. Caminhos para transformação da escola 4. Trabalho, agroecologia e estudo nas escolas do campo. São Paulo: Expressão Popular, 2017.

Carvalho, H. M. Na sombra da imaginação (3): o camponês e a superação de um destino medíocre. Curitiba, agosto de 2010 (mimeo).
Costa, J. J. D. Apontamentos sociohistóricos para uma discussão sobre a Agroecologia no Semiárido Brasileiro. In: Ribeiro, D. S.; Tiepolo, E. V.; Vargas, M. C.; Silva, N. R. (Orgs.). Agroecologia na educação básica: questões propositivas de conteúdo e metodologia. São Paulo: Expressão Popular, p. 153-160, 2017.

Fernandes, I. V.; Barbosa, L.P. A construção da agroecologia no semiárido. A Metodologia De Camponês a Camponês no Assentamento Santana, Ceará, Brasil. In: Torres Salinas, R. et al. Senti-pensarnos tierra. Experiencias de transición y r-existencias en tiempos de crisis civilizatoria: voces desde los pueblos del Abya Yala. Buenos Aires: CLACSO, p. 72-80, 2020.

Fontes, M. A. Nós aqui somos um barco de aprender com o outro: redes de agroecologia na construção da autonomia camponesa. Aracajú, Tese (Doutorado em Geografia) UFS, 2019.

Freire, P. ¿Extensión o comunicación? La concientización en el medio rural. Argentina: Siglo Veintiuno editores, 1973.

Giraldo, O. F.; McCune, N. Can the state take agroecology to scale? Public policy experiences in agroecological territorialization from Latin American. Agroecology and Sustainable Food Systems, 43(7-8), 785-809, 2019.

Gliessman, S. R. Agroecologia: processos ecológicos em agricultura sustentável. Porto Alegre: Editora da UFRGS, 2000.

Grammont, H. C. La construcción de la democracia en el campo latinoamericano. Buenos Aires: CLACSO, 2006.

Guhur, D. M. P.; Toná, N. Agroecologia. In: Caldart, R. S. et al. (Org.). Dicionário da educação do campo. São Paulo: Expressão Popular, p. 57-64, 2012.

Holt Giménez, E. Campesino a Campesino. Voces de Latinoamérica: Movimiento Campesino para la Agricultura Sustentable. Managua: SIMAS, 2008.

Khadse, A.; Rosset, P. M.; Morales, H.; Ferguson, B. G. Taking agroecology to scale: the Zero Budget Natural 
Farming peasant movement in Karnataka, India. Journal of Peasant Studies, 45(1), 192-219, 2017.

Kolmans, E. Construyendo procesos 'de Campesino a Campesino’. LIMA: Espigas y Pan para el Mundo, 2006.

Lazzari, F. M.; Souza, A. S. Revolução Verde: impactos sobre os conhecimentos tradicionais. In: Anais do $4^{\circ}$ Congresso Internacional de Direito e Contemporaneidade: mídias e direitos da sociedade em rede. Santa Maria, RS, 8 a 10 nov., 2017. Disponível em <http://coral.ufsm.br/congressodireito/ anais/2017/4-3.pdf>. Acesso em: dez., 2017.

LVC - Via Campesina Internacional. De Maputo a Yakarta: 5 años de agroecología en La Vía Campesina. Yacarta: LVC, 2013.

LVC - Via Campesina Internacional. Relatório do Encontro. In: Anais do I Encuentro Continental de Formadores y Formadoras en Agroecología. Barinas, Venezuela, ago. 2009.

Machín Sosa, B.; Roque Jaime, A. M.; Ávila Lozano, D. R.; Rosset, P. M. Revolução agroecológica: o movimento de camponês a camponês na ANAP em Cuba. São Paulo: Outras Expressões, 2012.

Martínez-Torres, M. E., Rosset, P. M. Diálogo de saberes in La Vía Campesina: food sovereignty and agroecology. Journal of Peasant Studies, 41(6), 979-997, 2014.

McCune, N.; Rosset, P. M.; Cruz, T.; Morales, H.; Saldívar, A. The long road: rural youth, farming and agroecological formación in Central America. Mind, culture, and activity 24(3), 183-198, 2017.

McCune, N., Rosset, P. M.; Cruz, T.; Saldívar, A.; Morales, $\mathrm{H}$. Mediated territoriality: rural workers and the efforts to scale out agroecology in Nicaragua. The Journal of Peasant Studies, 44(2), 354-376, 2016.

Mier y Terán, M. G. C.; Giraldo, O. F.; Aldasoro, M.; Morales, H.; Ferguson, B. G.; Rosset, P. M.; Khadse, A.; Campos, C. Bringing agroecology to scale: key drivers and emblematic cases. Agroecology and Sustainable Food Systems, 42(6), 637-665, 2018.

Moyo, S.; Yeros, P. Recuperando la tierra. El resurgimiento de los movimientos rurales en África, Asia y América Latina. Buenos Aires: CLACSO, 2008.
MST-CE - Movimento dos Trabalhadores Rurais Sem Terra do Ceará. Construindo a Agroecologia no Semiárido: Manual da metodologia Camponês a Camponês. Fortaleza: MST-CE/ CCA, 2019.

MST - Movimento dos Trabalhadores Rurais Sem Terra. Programa Agrário do MST. Lutar, Construir Reforma Agrária Popular! São Paulo: Secretaria Nacional do MST, 2014.

Primavesi, A. Manual do solo vivo: solo sadio, planta sadia, ser humano sadio. São Paulo: Expressão Popular, 2016

Ribeiro, D. S. et al. Agroecologia na educação básica: questões propositivas de conteúdo e metodologia. São Paulo: Outras Expressões, 2017a.

Ribeiro, D. S. et al. Educação em agroecologia: percurso da construção de uma proposta pedagógica para as escolas do campo do Extremo Sul da Bahia. In: Caldart, R. S. (Org.). Caminhos para transformação da escola 4. Trabalho, agroecologia e estudo nas escolas do campo. São Paulo: Expressão Popular, p. 37-55, 2017 b.

Roque Jaime, A. M. A Metodologia do Camponês a Camponês aplicada em Cuba. In: MST. Construindo a agroecologia no semiárido: Manual da Metodologia Camponês a Camponês. Fortaleza: MST, p. 35-46, 2019.

Rosset, P. M. Social organization and process in bringing agroecology to scale. In: Proceedings of the FAO International Symposion. Agroecology for food security and nutrition. Rome, 18-19 sept., 2015. Disponível em: <http:// www.fao.org/3/a-i4729e.pdf>.

Rosset. P. M. A territorialização da agroecologia na disputa de projetos, e os desafios para as escolas do campo. In: Ribeiro, D. S. et al. (Orgs.). Agroecologia na educação básica: questões propositivas de conteúdo e metodologia. São Paulo: Outras Expressões, 2017. p. 83-92.

Rosset, P. M.; Altieri, M. A. Agroecology: science and politics. London: Practical Action Publishing, 2017.

Rosset, P. M.; Barbosa, L. P. Territorialização da agroecologia na Via Campesina. Boletim EcoEco, 39, 46-52, 2019.

Rosset, P. M.; Barbosa, L. P. Autonomía y los movimientos sociales del campo en América Latina: un debate urgente. Aposta, Revista de Ciencias Sociales, 89, 8-31, 2021. 
Rosset, P. M.; Machín Sosa, B.; Roque Jaime, A. M.; Ávila Lozano, D. R. The Campesino-to-Campesino agroecology movement of ANAP in Cuba: social process methodology in the construction of sustainable peasant agriculture and food sovereignty. The Journal of Peasant Studies, 38(1), 161-191, 2011.

Rosset, P. M.; Martínez Torres, M. E. Agroecología, territorio, recampesinización y movimientos sociales. Estudios Sociales. Revista de Investigación Científica, 25(47), 275-299, 2016.

Rosset, P. M.; Val, V.; Barbosa, L. P.; McCune, N. Agroecology and La Via Campesina II. Peasant agroecology schools and the formation of a sociohistorical and political subject. Agroecology and Sustainable Food Systems, 43(78), 895-914, 2019.
Sampaio J. L. F.; Lima, A. E. F. O saber camponês: apropriação dos Recursos no Sertão dos Inhamuns - CE. Revista Mercator, 6(11), 59-70, 2007.

Shiva, V. Monoculturas da mente: perspectiva da biodiversidade e da biotecnologia. São Paulo: Gala, 2003.

Silva, V. I. Classe camponesa: modo de ser, de viver e de produzir. Porto Alegre: Padre Jósimo, 2014.

Stedile, J. P. A questão agrária no Brasil. O debate na década de 1990. São Paulo: Expressão Popular, Tomo 6, 2013.

Val, V.; Rosset, P. M.; Zamora Lomelí, C.; Giraldo, O. F.; Rocheleau, D. Agroecology and La Via Campesina I. The symbolic and material construction of agroecology through the dispositive of "peasant-to-peasant" processes. Agroecology and Sustainable Food Systems, 43(7-8), 872894, 2019. 